\title{
Community Understanding of Sustainable Communal Cattleshed Management
}

\author{
Muhammad Febriman $\mathrm{S}^{1}$, Tri Edhi Budhi Soesilo ${ }^{2}$, Evi Frimawaty ${ }^{3}$ \\ School of Environmental Science, Universitas Indonesia, Jakarta, Indonesia ${ }^{1,2,3}$ \\ $\left\{\underline{\text { febri923336@gmail.com }}{ }^{1}\right\}$
}

\begin{abstract}
The management of beef cattle in Indonesia is still managed individually by farmers. This condition causes low awareness of farmers to manage livestock waste because it is considered not to be of economic value. Managing livestock for production and handling waste is more efficient when using a communal enclosure system. Hence the purpose of this study is to analyze community understanding of sustainable communal cattle shed management. This study generally uses a quantitative approach. The research method used is a mixture (mix method) of quantitative and qualitative methods. The research data were analyzed by descriptive statistical analysis procedures and using SPSS 19.0 software. The relationship of community behavior with an understanding of sustainable communal cattle-shed was tested using Kendall's Tau correlation. Based on the results of the analysis of the relationship and the influence and conditions in the field, all variables observed had a significant relationship, had a significant and direct effect on community understanding of communal cattleshed management.
\end{abstract}

Keywords: Communal, Management, Farmers

\section{Introduction}

The livestock sector in Indonesia is mostly small-scale livestock businesses because they are in a rural environment and the technology used is still simple or traditional. Livestock businesses in Indonesia are dominated by people's businesses using traditional methods, still in the form of side businesses and become one of the indicators of social status in the community [1]. The development of the sector is currently not only related to the fulfillment of food but also related to health and the environment. The impact of this sector is on environmental pollution (ammonia, greenhouse gases, and pathogens). Intensive livestock production will contribute to the level of environmental pollution, including disposal of soil and surface water and emissions to the atmosphere [2].

The management of beef cattle in Indonesia is still managed individually by farmers. This condition causes low awareness of farmers to manage livestock waste because it is considered not to be of economic value. Managing livestock for production and handling waste is more efficient when using a communal enclosure system. The colony (communal) or group cattleshed is a cattle-shed model in a room that places several livestock, freely without being tied, serves as a place of marriage and enlargement of children until weaned, or used as a cattle- 
shed for enlargement and fattening [3]. Communal cattle-shed are expected to increase reproductive success and efficient use of labor. In addition, the management model through communal enclosures provides a more efficient level of waste management efficiency because it is managed centrally.

Maintenance of beef cattle using sustainable communal cattle shed can increase the income of beef cattle farmers and minimize the impact of the waste on the environment. The use of this sustainable concept can also play an active role in reducing the greenhouse effect where cattle waste is processed into sustainable alternative energy and becomes one of the most appropriate alternatives to overcome the rising fertilizer prices and scarcity of fuel oil. The more intensive management of cattle waste is expected to be able to help cattle breeders' families to gain access to energy by using biogas. Therefore, a beef cattle business must be built continuously so that it can provide a large and sustainable income contribution. Based on these problems, the question of this research is how is the community's understanding of the management of communal cattle-shed? Based on the background and formulation of the problems presented above, the purpose of this study is to analyse the community's understanding of the management of sustainable communal cattle-shed.

\section{Method}

This study generally uses a quantitative approach. The quantitative approach is used because the research carried out requires objective, independent, systematic and measurable assessment. Data collection and analysis is done with quantitative methods. The research method used is a mixture (mix method) of quantitative and qualitative methods. This research was conducted for 6 (six) months, starting in July 2017 until December 2017. The activities carried out included the collection of primary data and secondary data, questionnaires, processing, and data analysis that had been obtained.

The population in this study was the population of household in MuaroPijoan village. The household of MuaroPijoan Village is a family that lives in MuaroPijoan Village, JalukoSubdistrict, Muaro Jambi District, Jambi Province. The total number of people in MuaroPijoan Village in 2016 was 471 households (BPS) [4]. Determination of the number of samples is done by Slovin formula with a 10 percent error degree [5]. Based on these criteria, the total sample of respondents obtained was 83 households. In order to anticipate outlier data and the minimum sample size can still be met, then when sampling in the field researchers will overestimate the number of samples to 95 households. The sample will be taken using a simple random sampling technique. However, respondents sampled must have to meet the following criteria. Adults, that is aged over 17 years; Healthy, which is recognized by the surrounding community, is not mentally disturbed; and willing to be a data source.

Data on community understanding were analyzed based on community understanding of sustainable communal cattle-shed management presented through a questionnaire. The research data were analyzed by descriptive statistical analysis procedures and using SPSS 19.0 software. Descriptive statistics (mean value, a frequency of distribution, and cross-tabulation) are used to group data on community understanding into several categories presented in the form of nominal and ordinal scales. Furthermore, the relationship of community behavior with an understanding of sustainable communal cattle-shed was tested using Kendall's Tau correlation. 


\section{Result and discussion}

Analysis of community understanding using non-parametric statistical analysis is to find out the level analysis using Kendall's Tau Correlation. Correlation analysis with Y as the dependent variable and independent variables X1, X2, X3, and X4. The dependent variable in this analysis is an understanding of the management of sustainable communal enclosures (Y), while the independent variable is the level of people's desire to use technology for beef cattle business (X1), the level of people's desire to increase the economy or income with cattle business (X2), the level of public knowledge about livestock waste management (X3), the level of people's desire to preserve the environment (X4).

Table 1. Relationships and Effects of Community Behaviour Variables with Understanding of Sustainable Communal Cattle-shed Management

\begin{tabular}{|c|c|c|c|c|}
\hline Variables & $\begin{array}{c}\text { Correlation } \\
\text { Coefficient } \\
\text { (r) } \\
\end{array}$ & $\begin{array}{c}\text { Determination } \\
\text { Coefficient } \\
\left(\mathbf{r}^{2}\right)\end{array}$ & $\begin{array}{l}\text { Sig. (2- } \\
\text { tailed) }\end{array}$ & Description \\
\hline $\begin{array}{l}\text { The level of people's } \\
\text { desire to use } \\
\text { technology for beef } \\
\text { cattle business (X1), }\end{array}$ & 0,457 & 0,208 & 0,009 & $\begin{array}{l}\text { There is a } \\
\text { relationship, the level } \\
\text { of relationship is } \\
\text { moderate, has a } \\
\text { significant and direct } \\
\text { effect }\end{array}$ \\
\hline $\begin{array}{l}\text { The level of people's } \\
\text { desire to increase the } \\
\text { economy or income } \\
\text { with cattle business } \\
\text { (X2) }\end{array}$ & 0,400 & 0,160 & 0,000 & $\begin{array}{l}\text { There is a } \\
\text { relationship, the level } \\
\text { of relationship is } \\
\text { moderate, has a } \\
\text { significant and direct } \\
\text { effect }\end{array}$ \\
\hline $\begin{array}{l}\text { The level of public } \\
\text { knowledge about } \\
\text { livestock waste } \\
\text { management (X3), }\end{array}$ & 0,684 & 0,467 & 0,000 & $\begin{array}{l}\text { There is a } \\
\text { relationship, a strong } \\
\text { level of relationship, a } \\
\text { significant and direct } \\
\text { effect }\end{array}$ \\
\hline $\begin{array}{l}\text { The level of people's } \\
\text { desire to preserve the } \\
\text { environment (X4) }\end{array}$ & 0,261 & 0,068 & 0,005 & $\begin{array}{l}\text { There is a } \\
\text { relationship, the level } \\
\text { of relationship is } \\
\text { weak, has a } \\
\text { significant and } \\
\text { unidirectional effect }\end{array}$ \\
\hline
\end{tabular}

1. Relationship and Effect of the Level of Public Desire to Use Technology for Beef Cattle Business against Understanding of Sustainable Communal Cattleshed Management. The correlation value between the variable levels of public desire to use technology for beef cattle business on an understanding of sustainable communal cattle-shed management is 0.457 or has a moderate level of relationship. Based on the direction of the correlation between the two variables, the direction of the correlation seen from the number of correlation coefficients is positive, which is 0.457 . This means that if the level of public 
desire to use technology for beef cattle business is high, the understanding of sustainable communal cattle-shed management will be high as well. Changes to the variable X1 affect the change in variable $\mathrm{Y}$ by 20.8 percent, the remaining 79.2 percent is influenced by other factors outside of X1. Most of the respondents who represent the community in the study area have high motivation for innovation, especially for the management of livestock business. On the contrary, a small portion of the community does not have the motivation to use technology due to a lack of knowledge and understanding of the technology.

2. Relationship and Influence of the Level of People's Desire to Increase Economy or Revenue with Cattle Livestock Businesses against Understanding of Communal Cattleshed Management. The correlation value between the levels of community desire to increase the economy or income with cattle business on the understanding of sustainable communal cattle-shed management is 0.400 or has a moderate level of relationship. Based on the direction of the correlation between the two variables, the direction of the correlation seen from the number of correlation coefficients is positive, which is 0.400 . This means that if the level of people's desire to increase the economy or income with high cattle business, the understanding of sustainable communal cattle-shed management will be high too. Most of the respondents who represent the community at the study site have high motivation and desire to benefit through cattle business. On the other hand, a small number do not yet have the motivation to benefit from livestock business because the community only manages livestock business as a side business.

3. Relationship and Influence of Community Knowledge Levels on Livestock Waste Management against Understanding of Communal Cattle-shed Management. The correlation value between the variable level of public knowledge about livestock waste management and the understanding of sustainable communal cattle-shed management is 0.684 or has a strong level of relationship. Based on the direction of the correlation between the two variables, the direction of the correlation seen from the number of correlation coefficients is positive, which is 0.684 . This means that if the level of public knowledge about livestock waste management is high, the understanding of sustainable communal cattle-shed management will also be high. Most respondents who have sufficient knowledge are mostly farmers who are members of groups and community members who actively participate in socialization and training on livestock waste management.

4. Relationship and Influence of the Level of Public Desire to Preserve the Environment Against Understanding of Communal Cattle-shed Management. The correlation value between the variable level of public desire to preserve the environment and the understanding of sustainable communal cattle-shed management is 0.261 or has a weak level of relationship. Based on the direction of the correlation between the two variables, the direction of the correlation seen from the number of correlation coefficients is positive, which is 0.261 . This means that if the level of people's desire to preserve the environment is high, the understanding of sustainable communal cattle-shed management will be high too. Based on the results of the study, most respondents who represent the community are less concerned about environmental sustainability. This is due to a lack of knowledge about the impact of waste on the environment, especially livestock waste. The level of desire to preserve the environment is in line with the community's understanding of communal cattle-shed management.

Although the concept of communal enclosures has many advantages, in the implementation, farmers prefer to use individual cattle-shed and manage their own livestock. 
In line with the research [6], not all beef cattle farmers are interested in entering a livestock farmer group (non-summit farmers) and implementing a communal cattle-shed system for various reasons. Non-Summit farmers, who generally still use traditional maintenance patterns, are characterized by, among other things, close retention locations that are even integrated with the owner's residence, low productivity and have not implemented maintenance management in their management. In addition to having an impact on environmental health problems due to disruption of odors pollution and the resulting waste, it also makes it one of the obstacles for the government (Animal Husbandry Service) during the guidance and counseling process [7]. Johnson in [8] describes that this relationship is in the context of expectations or information about prior performance predicting the current level of performance.

A wide range of theories about human behavior according to [9] which he calls social learning theory. This theory explains directly how humans learn directly from their experiences as well as possible and make it something that has been observed as a model. Bandura also added that social learning theory explains human behavior as a construct of the social environment and cognitive factors of every human being. Bandura's theory that needs to be remembered is that the process of learning to follow something starts from the stage of paying attention, reminding, movements to recreate, and directing according to encouragement. The basic principle of learning this theory, that which is learned by individuals, especially in social learning and morel, occurs through imitation and presentation of modelling behaviour.

Based on the results of the analysis of the relationship and the influence and conditions in the field, all variables observed had a significant relationship, had a significant and direct effect on community understanding of communal cattle-shed management. The measured variable is the level of people's desire to use technology for beef cattle business, the level of people's desire to increase the economy or income with cattle business, the level of community knowledge about livestock waste management, the level of people's desire to preserve the environment. The variable level of community knowledge about livestock waste management has a strong relationship with an understanding of communal cattle-shed management. Whereas the variable level of community desire to preserve the environment has a weak relationship with an understanding of communal cattle-shed management. Research [6] states that in general the motivation of farmers to participate in forming communal cattle-shed is not solely based on economic benefits, to get an award or to be recognized for its existence, but rather based on encouragement to improve the quality of social life relationships between farmers or society. In line with the research [10], Revenue from beef cattle business comes from livestock sales, increase in livestock value and sales of livestock fertilizers. Breeders maintain beef cattle as part of optimizing the farmer's family resources in producing benefits in the form of calves, increasing the value of livestock and manure for fertilizer [11].

\section{Conclusion}

The test results of the relationship and influence of public understanding of communal cattleshed management showed that the level of community desire to use technology for beef cattle business (X1), the level of people's desire to increase the economy or income with cattle business (X2), community knowledge about waste management livestock (X3), the level of people's desire to preserve the environment (X4) has a real relationship, has a significant effect and is in line with the understanding of sustainable communal cattleshed management $(\mathrm{Y})$. 


\section{References}

[1] S.Nastiti, “'Penampilan Budidaya Ternak Ruminansia di Pedesaan Melalui Teknologi Ramah Lingkungan', Seminar Nasional Teknologi Peternakan dan Veteriner.” 2008.

[2] Foged et al., "Inventory of manure processing activities in Europe Technical Report No. I to the European Commission, Directorate-General Environment, Manure Processing Activities in Europe - Project reference: ENV.B.1/ETU/2010/0007," the European Commission, Directorate-General Environment, Brussels, 2011.

[3] Peternakan Puslitbang, Pedoman Teknis Pengembangan Usaha Integrasi Ternak dengan Tanaman. Jakarta: Direktorat Jenderal Peternakan Kementerian Pertanian, 2010.

[4] BPS, Kecamatan Jambi Luar Kota dalam Angka. Jambi: Badan Pusat Statistik, 2017.

[5] Sugiyono, Metode Penelitian Kuantitatif Kualitatif dan Kombinasi (Mixed Methods). Bandung: Alfabeta, 2016.

[6] P. Widiyaningrum, "Motivasi Keikutsertaan Peternak Sapi Potong pada Sistem Kandang Komunal (Studi Kasus di Kabupaten Bantul Yogyakarta)," Maj. Ilm. Peternak., vol. 8, no. 3, pp. 1-11, 2005.

[7] I. M. Nitis, "Masalah dan Prospek Penyediaan Makanan Ternak Sapi dan Kerbau di Indonesia," in Makalah Seminar Lustrum IX, 1992.

[8] D. M. Szymanski and D. H. Henard, "Customer Satisfaction: A Meta-Analysis of the Empirical Evidence,” J. Acad. Mark. Sci., vol. 29, no. 1, pp. 16-35, Jan. 2001.

[9] A. Bandura, "Self-efficacy," in Encyclopedia of human behavior, vol. 4, V. S. Ramachaudran, Ed. New York: Academic Press, 1994, p. 71-81[1] A. Bandura, "Self-efficacy," in Encyclope.

[10] M. Sugiarto and N. Syarifudin, "Optimalisasi Peran Agribisnis Sapi Potong Terhadap Pendapatan Keluarga Pada Tipe Pemeliharaan Yang Berbeda di Kabupaten Banjarnegara Propinsi Jawa Tengah,” in Seminar Nasional Optimalisasi Sumberdaya Lokal pada Peternakan RakyatBerbasis Teknologi, 2008, pp. 247-251.

[11] B. Hartono and E. S. Rohaeni, "Contribution to income of traditional beef cattle farmer households in Tanah Laut Regency, South Kalimantan, Indonesia," Livest. Res. Rural Dev., vol. 26, no. 8, 2014. 